\title{
Exploring the Perceptions of Secondary Education Students on the Nature of the Subject of Religious Education
}

\author{
Apostolia Kosta, and Adamos Anastasiou
}

\begin{abstract}
The purpose of the article is to contribute to the improvement and upgrading the view of the subject of Religious Education nowadays, by studying the way young people experience its teaching and the problems that they face. In the present research, the perceptions of 147 Secondary Education students concerning the necessity of the subject of Religious Education, as well as the role that the teacher plays in the teaching of this subject, are presented. In the following field research, by selecting random sampling, the relationship of students with the value and purpose of religion in general, as well as their perceptions on the nature of the subject of Religious Education in particular, are presented through descriptive analysis and the use of anonymous questionnaires. As presented in detail in the conclusions of the research, the majority of the respondents believe in God, are satisfied with the teaching of this subject and consider the teacher and his/her transmissibility directly responsible for accepting or not the teaching of this subject.
\end{abstract}

Index Terms-religious education, students' perceptions, teachers' attitudes

\section{INTRODUCTION}

The issue of religious education has occupied various scientific fields, such as Sciences of Education, Theology, Sociology etc., as well as society itself, the state and its institutions.

Religious education is obviously a pedagogical and also a worldwide phenomenon [1]. It is offered directly or indirectly, overtly or covertly, systematically or dimensionally - occasionally to all students of all grades and eras in general. "As an educational good, it is offered mainly, regardless of the existing political systems and party ideologies of each country, on the condition that the state considers the religious teaching in its schools as socially beneficial" [2].

In recent years, a fruitful discussion has begun around the physiognomy and the content of the subject of Religious Education. The proposals that have been submitted and even those chosen among them are various, in the perspective of changing the narrow confessional example in the religious filed. Based on this particular perspective, our main goal is to highlight the importance of the subject of Religious Education, the preservation of its confessional nature and the firm morals and principles that it stands for [3].

It is clear that occasionally there are intense speculations, objections and questions concerning the maintenance of the obligatoriness of the subject of Religious Education, and all

Published on March 29, 2021

Apostolia Kosta, Aristotle University of Thessaloniki, Greece.

(e-mail: apostoliaa@ ${ }^{@}$ hotmail.gr) these in a society in which the cultural and religious tradition has such a spiritual scope, going beyond the limits of Greek territory. The issue of the content and the orientation of the subject of Religious Education in public education often arises, at a time when both cultural and religious tradition of ${ }^{1}$ the Orthodox Church can constitute educational goods, capable of enriching the Greek educational reality [4].

The subject of Religious Education is a reason and an occasion of a perennial and intense debate in terms of all the other distinct subjects of the modern Greek educational system [5]. Through the present study, an attempt is made to ascertain the students' perceptions on the subject of Religious Education and more specifically of the students in secondary education, as well as their attitudes towards the respective teacher who teaches this subject.

\section{THE NECESSITY OF THE SUBJECT OF RELIGIOUS EDUCATION}

In recent years, the subject of Religious Education has become a "point of conflict" and there is a systematic reaction against it. The reduction of its teaching hours, its disappearance from the modern school and the change in its teaching content are sought.

The view that the subject of Religious Education must have a solely religious - epistemological, cultural character and not be marked as a "CONFESSIONAL" subject is expressed. In such a case, those who deny the confessional nature of this subject and do not take into account the Great

Teacher, the Teacher Christ -who did not adapt His teaching according to the listeners, nor gave it a Cultural Content- as unfortunately some theologians today suggest, make a mistake [6].

As a result, some argue that the subject offends the freedom

of religious conscience and that it must acquire a cultural character. However, this is not true, because these students can be exempted from attending this particular school subject. Nevertheless, there are several foreign students who attend the subject of Religious Education voluntarily and with great zeal [7].

Moreover, according to an epistemological point of view, "in the subject of Religious Education, the Christian education is not meteoric, neither temporary nor indefinite, but it is a divine-human education, as long as it is accomplished with a divine and human synergy". In this way, the subject of Religious Education is not an teaching object for education with a limited mission in the classroom, but is marked as a good of great importance for school and life,

Adamos Anastasiou, Hellenic Open University, Greece. (e-mail: adamosana@gmail.com) 
since within the person of Christ and love everything is summarised [8].

The subject of Religious Education is part of the Greek school and aims to raise awareness and set children towards religion with responsibility and in fact towards Orthodoxy, which is the predominant religion in Greece. The content of the subject of Religious Education does not aim to attract followers, neither to make "proselytism" [9].

Consequently, the subject of Religious Education trains people - individuals in order to become aware of religions, as well as the religious tradition of their place, to develop and cultivate resistance towards fanaticism and intolerance and also to develop fundamental values that are essential both for their personal life and their relationship with society. Additionally, it points out and promotes principles that are considered right for the smooth integration of every individual in the environment and the assurance of healthy social relations in general [10].

\section{THE EXISTENCE - PRESENCE OF THE THEOLOGY TEACHER FOR THEACHING THE SUBJECT OF RELIGIOUS EDUCATION}

What today's "times" require is not to develop within the field of Theology tendencies and groups with views and ideas that create confusion, but new teaching methods instead. In all the above, the presence of the teacher of Religious Education is effective. The teacher must not alter the content and the character of the subject but through the appropriate teaching on his/her part epistemological, cultural and experiential elements should emerge. The subject of Religious Education has several dimensions, such as religious, salvage, psychological, socio-moral, pedagogical, cultural, which are not marked by one-sidedness and fanaticism [6]. These aspects of the subject are "obliged" to be expressed - projected - promoted by the teacher in his/her effort to maintain the traditional nature of the subject even through modern ways of teaching [11].

What is extremely important in the teaching of Religious Education is the dynamic relationship of the teacher's personality towards the religious truth. The teacher of Religious Education, apart from theoretical training, must be an enlightened educator [9]. He/she must penetrate the students' soul and participate in their reflection with love [8].

For the success of this subject, the effective attitude of the teacher is essential. In particular, his/her role regarding his/her attitude towards faith, moral life, traditional principles and values advocated in the content of the subject of Religious Education, are a basic presupposition for an effective work within the school [12].

At the same time, this subject should meet the requirements and expectations of students. It must be proportionate to their capabilities and adapted to their needs and concerns. It is useful to ensure the active participation of students in all this. Consequently, the role of the teacher is crucial, who with his friendly and discreet attitude will organize an "open" Religious teaching, away from intolerance and dogmatism [13].

In addition, the cognitive content of the subject of Religious Education is required not to be cut off from the personal experiences and ethics of the students but be linked instead to their innermost values and beliefs instead. Therefore, the configuration of the subject content needs to be adapted in such a way that it can meet the requirements of the lifestyle and the timeless values each student stands for, but without altering the "virgin" nature of the subject [8].

\section{PURPOSE OF THE STUDY}

The initial point of interest was the investigation of the perceptions of secondary education students concerning the acceptance of the obligatoriness of the subject of Religious Education. Through this research, the attitudes of the students and their disposition towards the maintenance of this subject in the Curriculum are revealed, as well as their perceptions regarding the role played by the teacher who teaches it. The purpose of the research was to examine the relationship of adolescents with religion and the subject of Religious Education taught in Greek schools, as well as their attitudes and perceptions towards the teachers who teach this specific subject.

\section{METHOD}

\section{A. Sampling}

This particular research approach is a "field - review" research, as it refers to the research methodology of the social sciences and belongs to the choices of quantitative research [14]. If we start from the sampling strategy, it is worth mentioning that we have chosen simple random sampling, which belongs to quantitative sampling with probability, and is considered the most accurate and popular form [15]. The researcher selects the participants or units for the sample, so that there are equal chances for the selection of population, highlighting the representativeness of the sample and offering the possibility of generalisations about it [16], [15]. Selection or exclusion from the sample is considered absolutely a matter of luck [14].

In the present research, 147 graduates of 5 Senior High Schools and 40 graduates of Secondary Education of the Prefecture of Kavala participated. A number was assigned to each school unit, which was then recorded in a statistical table. From this table, 5 numbers were randomly selected representing 5 different schools, regardless of their location and number of classes. According to Robson [16], the selection of sampling is the easiest way for the quick and effective collection of large data from a big number of individuals, while at the same time it ensures anonymity encouraging honesty in responses.

\section{B. Research Tool}

Data collection was performed using a questionnaire. Creswell [15] claims that the questionnaire is the most ideal research tool for a quantitative survey, because it allows the researcher to collect data from a large sample and generalise results for an even larger population. Using questionnaires we made an effort to detect the pedagogical results of the teaching of Religious Education in secondary education, as they are expressed anonymously by students and graduates of secondary education. We then evaluated the students' 
recorded suggestions for a more creative lesson. It is worth mentioning that the written questionnaire was anonymous and structured with closed-ended questions.

The questionnaires were distributed by hand to the students of each school unit. In order to exclude any form of influence or fear from the participants' responses, we assured that we would maintain anonymity in the responses and that they would be used for research purposes. The researcher and also the teacher of each school unit were not present during the completion of the questionnaires and each student had the opportunity to answer them in his/her own space and time.

The researcher and each student had a communication before the distribution of the questionnaires, so that he/she was informed about the type and the purpose of the research and also the duration of the available time for completing the questionnaire. The questionnaires were collected by the students themselves 15 days after their distribution in each school unit, thus reducing the possibility of error.

According to [16], in order to ensure the validity of the questionnaire, the questions were as simple and clear as possible, aiming at avoiding difficulties in answering them. To ensure the above, the functionality and clarity of the questionnaire were checked, distributing it to 10 students.

\section{FINDINGS}

Respondents were of both genders, with almost balanced percentages, that is $54 \%$ for female and $46 \%$ for male participants. The majority of the participants (93\%) were between the age of 17 and 18 years old. Of crucial importance for the students' views concerning the subject of Religious Education are their opinions about Religion. More than three fourths of the respondents, that is specifically $82 \%$, believe in the existence of God. The percentage of $8 \%$ does not believe in the existence of God and $10 \%$ believe in something similar.

\begin{tabular}{ll}
\multicolumn{2}{c}{ TABLE I: BELIEVE IN GOD } \\
\hline \hline Response & Percentage \\
\hline Yes & $82 \%$ \\
In something & $10 \%$ \\
similar & $8 \%$ \\
No & $8 \%$ \\
\hline \hline
\end{tabular}

Of the $82 \%$ who believe in the existence of God, $47,83 \%$ are women and $34,17 \%$ are men. Also, out of the $12 \%$ who do not believe in God, $6,7 \%$ are men and 1,3\% are women. Finally, $10 \%$ of the children who participated stated that they believe in something similar. Of these, $5.4 \%$ are men and $4.6 \%$ are women.

TABLE II: PERCENTAGE ABOUT GENDER BELIEVING IN GOD OR

\begin{tabular}{llll}
\multicolumn{4}{c}{ NOT } \\
\hline \hline Gender & Yes & No & $\begin{array}{l}\text { In } \\
\text { something } \\
\text { similar }\end{array}$ \\
\hline Men & & & $5.4 \%$ \\
Women & $34.17 \%$ & $6.7 \%$ & $4.6 \%$
\end{tabular}

The majority of the respondents also claim that the subject of Religious Studies is interesting, either a lot (33\%) or a little (44\%). Only 14\% find it boring or find another negative element. The $9 \%$ almost did not answer.

\begin{tabular}{l}
\multicolumn{4}{c}{$\begin{array}{l}\text { TABLE III: STUDENTS' VIEWS ON THE SUBJECT OF RELIGIOUS } \\
\text { EDUCATION }\end{array}$} \\
\begin{tabular}{llll} 
Very interesting & $\begin{array}{l}\text { Of little } \\
\text { interest }\end{array}$ & Boring & Other \\
\hline $33 \%$ & $44 \%$ & $14 \%$ & $9 \%$
\end{tabular}
\end{tabular}

Of the $33 \%$ who claim that the subject of Religious studies is very interesting, $26.13 \%$ are women and $6.87 \%$ are men. The percentage of $44 \%$, claim that Religious studies is a little interesting, of which $23.7 \%$ are men and $20.3 \%$ are women. The percentage of $14 \%$, of the respondents, claim that Religious studies is boring. Of this percentage, $9.1 \%$ are men and $4,9 \%$ are women. Finally, $9 \%$ of the participants did not choose any of the options of the questionnaire, but wrote their own opinion about the Religious studies. Of their percentage (9\%), $6.5 \%$ were men and $2.5 \%$ women.

TABLE IV: PERCEPTIONS ABOUT THE SUBJECT OF RELIGIOUS EDUCATION BASED ON GENDER

\begin{tabular}{lllll}
\hline \hline Gender & Very interesting & Of little interest & Boring & Other \\
\hline Men & $6.87 \%$ & $23.7 \%$ & $9.1 \%$ & $6.43 \%$ \\
\hline Women & $26.13 \%$ & $20.3 \%$ & $4.9 \%$ & $2.57 \%$
\end{tabular}

According to the respondents' views, the majority of them (52\%) believe that the subject of Religious Education contributes to overcome the stereotypes that create social and racial discrimination. The respondents believe that Religious studies respect very much the difference of the other, while only $26 \%$ gave the answer «moderate».

TABLE V: CONTRIBUTION OF THIS SUBJECT TO THE RESPECT

\begin{tabular}{ll}
\multicolumn{2}{c}{ AND DIVERSITY OF OTHERS } \\
\hline \hline Response & Percentage \\
\hline High & $52 \%$ \\
Moderate & $26 \%$ \\
Little & $11 \%$ \\
Zero & $8 \%$ \\
Other & $3 \%$ \\
\hline \hline
\end{tabular}

The majority of respondents $(40 \%)$, do not often go to church but only a few times a year, $13 \%$ almost always and $12 \%$ answered always. In addition, $20 \%$ believe that they should not go to church in order to prove their faith in God and $15 \%$ of the respondents answered that do not go never in church.

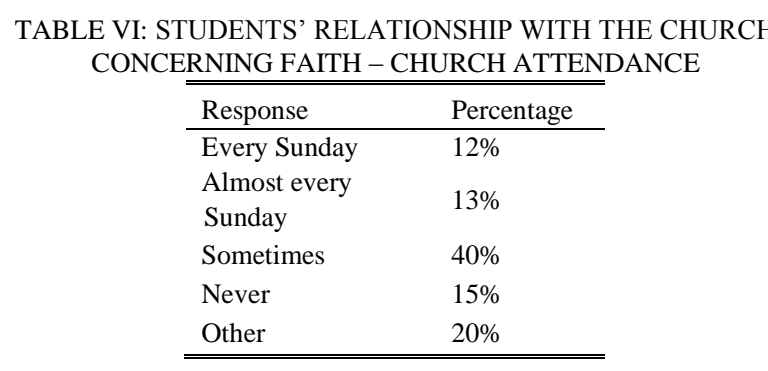

The views of the respondents about the teachers of the subject of Religious Education are satisfactory in general. $47 \%$ believe that teachers are very effective and make every 
possible effort to teach the subject in an efficient way, while $30 \%$ believe that they are simply good and typical in their work. The way the subject is taught and examined leaves satisfied most of the students, as $44 \%$ of them believe that it is "very satisfactory". The majority of students believe that the teacher is entirely responsible for the effectiveness of the teaching subject. It is worth noting the very positive view of students about the attitude of teachers towards other religion school students with a percentage of $78 \%$. This percentage has not felt racism by their teacher because of the different religion they have chosen. Thus, we conclude that the teaching of the subject of Religious Education is effective on the teachers' part, since most of them respond satisfactorily, without religious distinctions.

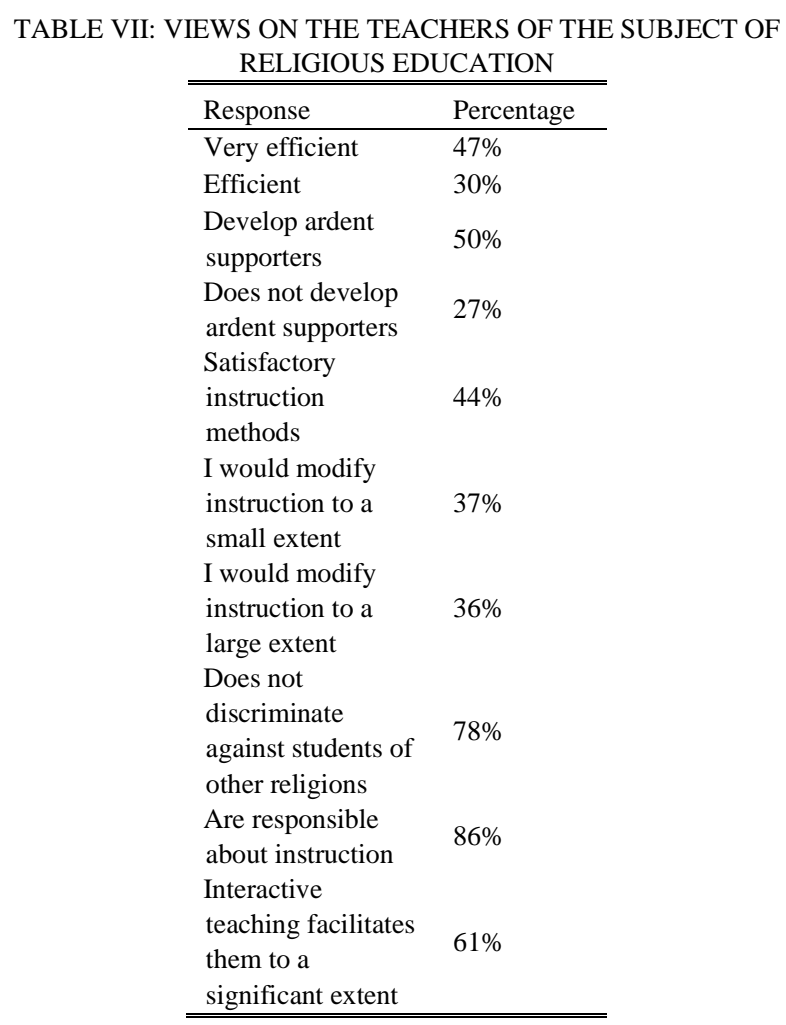

\section{CONCLUSIONS}

The bottom line is that the subject of Religious Education, whatever form it may take o $\rho$ whatever character it may stand for, must make students think freely, seek God for themselves, become free-thinking people who will reflect on the issues of human existence and interaction with his/her natural environment and especially his/her relationship with fellow human beings, learn to respect and love but without unquestioningly accepting what the teacher imposes on them.

Each school subject must help in the psychosomatic development of the student, in the formation of his critical ability and in the development of his/her free personality. Apart from the percentages of faith, promotion of religious piety or church visits, students nowadays believe that this subject must remain mandatory. Most students may not consider church attendance as proof of their faith, but they believe that faith is something personal and expressed in different ways by each individual personally.
Furthermore, the ideals, the manners and the values of the subject fascinate most students who unreservedly support the obligatoriness of the teaching of this subject. Some students may not find the traditional nature of the subject completely interesting, but they are still satisfied with the teaching process followed by the teachers of the subject of Religious Education. Besides, the traditional nature of this subject is the one that supports it and maintains its importance.

According to this research, the teacher is not a mobile encyclopaedia that provides the children with barren knowledge, as if they are inanimate objects. It is revealed that the teachers of the study have a duty to create free people and not subordinates of a non-free system who are trapped in the curriculum.

As a result, it is the duty of every teacher, especially the one of the subject of Religious Education, which promotes in particular and to a greater extent the morals, the values and the ideals, to instil in the souls of students the love for research and knowledge and to contribute to the breadth of spirit. The present research highlights the current attitude of students in a not so popular school subject and its results are a positive omen for the content of the subject of Religious Education, as well as for the teachers who, with their effort, continue to keep it at an adequate level and also strengthen it with faith, hope and dignity.

\section{REFERENCES}

[1] Koukounaras-Liagkis, M., (2013). The Religious Lesson today and tomorrow. A point of view based on the pedagogical and didactic of the course. New Education, 146, 123-135.

[2] Vagianos, G., (1989). Religious education in primary education, Thessaloniki: Andronaki, p. 389.

[3] Giagazoglou, S., (2005). The physiognomy and character of the religious lesson. Religious education in modern multicultural societies. Assembly, 93, 39-52.

[4] Stogiannidis, A., (2016). The Course of Religious in Public Education: a Course of Positions, Meditation and Interpretation. Synthesis, 5 (1), 41-67.

[5] Sotirelis, G., (1993). Religion and Education. Athens: Ant. N. Sakkoulas.

[6] Pontikas M. (2015). Climax, Purple Squirrel, Athens 2015.

[7] Debre (2004) The Teaching of Religion in the Neutral Religious School, trans. G. Karabelas, published by Estia, Athens , pp. 68-132.

[8] Portelanos, S., (1999). Didactics of the Religious Lesson: An approach through philosophical reflection and the Neptic tradition. Athens: Grigori.

[9] Micheloudakis, S., \& Pepes, E., (2014). The course of Religious Studies, Thessaloniki, Proceedings of the Panhellenic Scientific Conference, pp. 151-160.

[10] Delikonstantis, K., (2009). The school religious education. Between pedagogy and theology. Athens: Concept.

[11] Boyer P., (2013). And man created the gods, Ed. Vanias, Thessaloniki, p.52

[12] Giannaras, Ch., (2004). Ontology of the relationship. Athens: Icarus. [13] Kogoulis, I., (2019). The so-called Religious Studies course as a course of authentic education and Greek Orthodox heritage. Society Magazine, 60 (1), 116-125.

[14] Cohen, L., Manion, L., \& Morrison, K., (2008).Research methods in education (S. Kiranakis, M. Mavraki, Ch. Mitsopoulou, P. Bithara, \& M. Filopoulou, trans.). Athens, Greece: Metaixmio.

[15] Creswell, J. W., (2011). Research Designs: Qualitative, Quantitative, and Mixed Methods Research. USA: Texas Publications.

[16] Robson, C., (2011). Real world research, A Resource for Social Scientists and Practitioner-Researchers, Second Edition. Oxford: Blackwell Publishing, 3-387. 